\title{
Komparativni pristup određivanju pojma, koncepta i fenomena personalizma
}

Ivan Čulo*

institutfs@gmail.com

Ivan Šestak**

isestaksj@gmail.com https://doi.org/10.31192/np.17.1.11

UDK: 141.144

1Maritain, J.

1Berdjaev, N. A.

Pregledni članak / Review

Primljeno: 22. siječnja 2019.

Prihvaćeno: 6. ožujka 2019.

U radu se prikazuju i analiziraju određenja personalizma u filozofskoj literaturi, osobito enciklopedistici i filozofskim rječnicima različitih jezičnih tradicija, filozofskih škola i razdoblja 20. stoljeća te iznosi pokušaj određenja tog filozofskog pravca kroz komparativnu perspektivu. Personalizam se u filozofskim, sociološkim, povijesnim i drugim tekstovima određuje kao filozofija, filozofski pravac, disciplina, škola, nauk, pokret, teorija, učenje i slično. Pri tome, govor o personalizmu ima različite konotacije, naglaske i obojanost, ovisno $i$ o povijesnom, geografskom, ili ideološkom kontekstu. Iako se kroz povijest filozofije mogu pratiti korijeni personalizma do antičkog doba, ipak se pojam personalizam vremenski uobičajeno veže uz 20. st. Razvidno je da u povijesnoj i zemljopisnoj difuziji ideja u modernoj misli postoji više oblika personalizama. Spominju se američki idealistički personalizam, ruski personalizam, različiti europski personalizmi, komunitarni kršćanski personalizmi i sl. Svaki od tih oblika ima svoje razumijevanje o osobi i stavlja je u središte filozofskog razmatranja. Korijeni personalističke filozofije po nekima sežu do antike, iako je uobičajen stav da je koncept osobe razvijen u susretu grčke filozofije i novog, kršćanskog načina razmišljanja. Na europskom kontinentu personalizam se obično veže uz tri škole: francusku u Parizu, njemačku u Göttingenu i Freiburgu te poljsku u Lublinu. Personalizam je imao odjek $i$ u drugim europskim državama. U Francuskoj personalizam nije bio samo filozofski pravac, već je imao brojne sljedbenike i u različitim personalističkim pokretima te se taj personalizam detaljnije obrađuje u drugom dijelu članku.

Ključne riječi: personalizam, europski personalizam, francuski personalizam, Jacques Maritain, Nikolaj Berdjajev.

\footnotetext{
* Dr. sc. Ivan Čulo, Institut Fontes Sapientiae, Kušlanova 59, HR-10000 Zagreb.

** Izv. prof. dr. sc. Ivan Šestak, Fakultet filozofije i religijskih znanosti Sveučilišta u Zagrebu, Jordanovac 110, HR-10000 Zagreb.
} 


\section{Uvod}

Povijest personalizma je povijest shvaćanja ljudske osobe, a korijeni personalističke filozofije po nekima sežu do antike, ${ }^{1}$ iako je uobičajen stav da je koncept osobe razvijen u sukobu grčke filozofije i novog, kršćanskog načina razmišljanja. ${ }^{2}$

Personalizam je snažno i prije i poslije Drugog svjetskog rata utjecao na mnoge grupe personalistički inspiriranih intelektualaca i političara. $\mathrm{O}$ personalizmu u Hrvatskoj se razmjerno malo pisalo ili su se iznosila preuska određenja personalizma, kao npr. "sinteze egzistencijalizma i marksizma $\aleph^{3}$ sagledavanjem samo lijevo orijentiranih političkih personalizama. $\mathrm{Na}$ ovim prostorima recepcija prema nemarksističkim, a osobito katoličkim misliocima i personalizmu, gotovo do osamostaljenja bila je izrazito negativna: od boljševičkih napada do svrstavanja u buržoasku propagandnu filozofiju. ${ }^{4} \mathrm{~S}$ propašću socijalizma ne dolazi do nove kvalitete u recepciji personalizma i personalističkih tema (demokršćanstvo, ljudska prava, europske integracije itd.), iako je bilo očekivano da se u društvu i državi koja mijenja državni i društveno-politički status ozbiljnije raspravlja i ukaže na vrijednost personalističkog pogleda na čovjeka i svijet.

U prvom dijelu rada ukazuje se na određenje personalizma u širem smislu, uglavnom iz filozofske enciklopedistike različitih reprezentativnih i prepoznatljivih tradicija, zemalja i razdoblja, a u drugom dijelu se analizira tzv. »francuski personalizam« na kojeg se u europskoj filozofskoj tradiciji uglavnom i misli kada se govori o »personalizmu«. U zaključku autori ukazuju na moguće određenje, odnosno značenje koje ima personalizam kao filozofski pravac.

S obzirom na to da je personalizam kao filozofski pravac, kao i mislioci koji se vežu uz taj pravac ili kasnije personalističke pokrete, slabije poznat na ovim prostorima u članku se kod prvog spomena pojedine osobe naznačuju i njene kronološke odrednice rođenja i smrti.

\footnotetext{
${ }^{1}$ Albert C. KNUDSON, The Philosophy of Personalism. A Study in the Metaphysics of Religion, New York Cincinnati, The Abingdon Press, 1927; Thomas O. BUFORD, Foreward, u: Jonas Norgaard MORTENSEN, The Common Good. An Introduction to Personalism, Frederiksvark, Boedal, 2014, 11.

2 Battista MONDIN, I valori fondamentali, Dino editore, Roma, 1985, 94; Denis de ROUGEMONT, Lettre ouverte aux européens, Albin Michel, Paris, 1970, 34.

${ }^{3}$ Vidi npr. Franjo ZENKO, Personalizam Emmanuela Mouniera. Pokušaj sinteze marksizma $i$ egzistencijalizma, Zagreb, Centar za povijesne znanosti, 1980.

${ }^{4}$ Ivan ČULO, Recepcija Emmanuela Mouniera u Hrvatskoj i bivšoj Jugoslaviji do 1965. godine, Nova prisutnost, 15 (2017) 1, 5-29, 28.
} 


\section{Određenje personalizma u filozofskim rječnicima $i$ enciklopedijama}

Prvo pojavljivanje personalizma u devetnaestom stoljeću je bilo nejasan filozofski pojam koji je imao mnogo različitih značenja. ${ }^{5}$ Pokušaj određenja nalazimo već početkom 20. st., iako se personalizam u to doba još nije razvio kao filozofski pravac, a ni kao pokret.

\subsection{Personalizam iz perspektive germanskih filozofskih rječnika}

Rudolf Eisler (1873-1926), najpoznatiji po nizu leksikografskih filozofskih djela s početka 20. stoljeća, navodi da personalizam u teoretskom smislu znači takav pogled prema kojemu se svijet sastoji od različitih osobnih bića, a kao predstavnike takvog sagledavanja navodi Gustava Teichmüllera (1832-1888), Christophera Jacoba Boströma (1797-1886), Charlesa Bernarda Renouviera (1815-1903) te Williama Sterna (1871-1938). Praktičan oblik personalizma objašnjava kao naglasak na osobnost ljudi, a što vidi kod Immanuela Kanta (1724-1804) i Johanna Gottlieba Fichtea (1762-1814). ${ }^{6}$

Pri kraju 20. st. u njemačkom povijesnom rječniku filozofije detaljan tekst o personalizmu potpisuje Michael Theunissen (1932-2015). Uz personalizam veže dva značenja. Prvo, da se tim pojmom označava ideja osobnog Boga kod Friedricha Schleiermachera (1768-1834) u djelu Über die Religion, dok raspravlja o personalizmu i panteizmu. Podsjeća da su Ludwig Feuerbach (1804-1872) te protestantski teolozi Ernst Troeltsch (1865-1923) i Gerhard Gloege (1901-1970) također spominjali dihotomiju personalizam - panteizam. U drugom značenju, personalizam određuje kao usmjerenost prema vlastitoj heterogenosti ili, $\mathrm{u}$ slučaju dijaloške filozofije, kao smjer od vanjskog razmišljanja najviše empatije prema konceptu različitosti osoba. Prikazuje potom razvoj pojma »osoba« kod Boecija (480-524) i Tome Akvinskog (1225-1274), supstancijalistički personalizam Hermana Lotzea (1817-1881) te njegov utjecaj na američke personaliste Georgea Trumbulla Ladda (1842-1921), Josiaha Roycea (1885-1916), Bordena Parkera Bownea (1847-1910) i Edgara Sheffielda Brightmana (1884-1953). Opisuje i utjecaj shvaćanja osobe Aurelija Augustina (354-430), Rikarda iz Svetog Viktora (1110-1173) i Ivana Duns Skota (1266-1308) na dijaloški personalizam. Spominje i pogled na osobnost W. Sterna, rasprave protestantskog teologa i filozofa Davida Friedricha Straussa (1808-1874) o individualitetu, supstancijalitetu i kauzalitetu te određenje osobe kod Martina Bubera (1878-1965), Ludwiga

\footnotetext{
${ }^{5}$ Jean LACROIX, Le personnalisme comme une anti-idéalogie, Paris, Presses Universitaires de France, 1972, 5-6.

${ }^{6}$ Rudolf EISLER, Wörterbuch der philosophischen Begriffe, sv. 2, Berlin, Verlegt bei Ernst Siegfried Mittler und Sohn, 1910, 993.
} 
Binswangera (1881-1966), Maxa Schelera (1874-1928), Petera Wursta (18841940), Romana Guardinija (1885-1968), Emmanuela Mouniera (1905-1950) i Nikolaja Berdjajeva (1874-1948). ${ }^{7}$

Alois Halder (r. 1928), profesor filozofije na Sveučilištu u Augsburgu, navodi da je personalizam izvorno oznaka za vjeru u osobnoga Boga koja se razgraničuje od panteizma. Po njemu, personalizam ima i drugo značenje, a to je: »oznaka za nazore u kojima čovjek kao osoba ima središnje značenje pri čemu se pojam osobe različito shvaća.$^{8}$ Posebno ističe »kršćanski personalizam« koji naglašava socijalnu »povezanost čovjeka kao osobe u zajedništvu s drugim osobama, čovjeka koji se ističe apsolutnom važnošću i dostojanstvom te koji je svrha samom sebi «. ${ }^{9}$ Kao predstavnike tog personalizma nabraja E. Mouniera, Louisa Lavellea (1883-1951), Renéa Le Sennea (1882-1954), N. Berdjajeva, M. Schelera i R. Guardinija. Uz personalizam veže i tematiziranje međuljudskog odnosa koji postaje prvorazrednom temom dijaloške filozofije, a kao predstavnike takvog smjera vidi M. Bubera, Ferdinanda Ebnera (1882-1931) i Franza Rosenzweiga (1886-1929).

U djelu Politička filozofija 20. stoljeća natuknicu o personalizmu potpisuje Sergio Belardinelli (r. 1952). Određuje personalizam kao povijesni i kulturni fenomen koji se razvio u Francuskoj, a kojeg je u obliku pokreta osnovao E. Mounier 1932. časopisom Esprit. Ukazuje na naročit razvoj personalizma u poslijeratnom razdoblju i u drugim europskim zemljama, SAD-u te Latinskoj Americi. Ističe da je personalizam duhovni pokret koji uviđa da se sloboda $\mathrm{i}$ ljudsko dostojanstvo moraju ponovno čvrsto utemeljiti nakon hegelijanizma i marksizma, koji su ih doveli u pitanje. Ukazuje i na personalističku političku razinu te njihovu borbu protiv marksizma, liberalizma i totalitarizama. Kao glavne predstavnike, pored E. Mouniera, ističe Jeana Lacroixa (1900-1986), Jacquesa Maritaina (1882-1973), Paul-Louisa Landsberga (1901-1944) i N. Berdjajeva. ${ }^{10}$

\subsection{Personalizam iz perspektive francuskih rječnika}

Književni kritičar i filozof Pierre André Lalande (1867-1963) za personalizam veže tri značenja. Prvo, doktrinu Ch. Renouviera koja tvrdi da je osoba najviša kategorija i središte svijeta. Drugo, kao moralni i socijalni nauk utemeljen na apsolutnoj vrijednosti osobe iznijet 1936. u djelu Personalistički manifest E.

\footnotetext{
7 Michael THEUNISSEN, Personalismus, u: Joachim RITTER, Karlfried GRÜNDER (ur.), Historisches Wörterbuch der Philosophie, sv. 7, P-Q, Basel - Stuttgart, Schwabe Verlag, 1998, 338-342.

8 Alois HALDER, Filozofijski rječnik, Zagreb, Naklada Jurčić, 2002, 267.

9 Isto, 267-268.

${ }^{10}$ Sergio BELARDINELLI, Die politische Philosophie des christlichen Personalismus, u: Graf Karl BALLESTREM, Henning OTTMANN (ur.), Politische Philosophie des 20. Jahrhunderts, München - Beč, Oldenbourg, 1990, 243-262.
} 
Mouniera. Lalande se poziva na Mounierov stav da se personalizam strogo razlikuje od individualizma zbog naglaska na kolektivnu i kozmičku ulogu osobe. Treće značenje personalizma vidi u doktrini onih koji misle da je Bog osoban. ${ }^{11}$

Filozof i prevoditelj Paul Foulquié (1893-1983) navodi da personalizam u svoju doktrinu uvodi $\mathrm{Ch}$. Renouvier. To je, po njemu, i moralni i socijalni nauk koji potvrđuje primat osobe te se protivi individualizmu. Svoje navode potkrepljuje stavovima M. Schelera i E. Mouniera. ${ }^{12}$

U Leksikonu filozofskih pojmova personalizam se opisuje citatima Ch. Renouviera te se prikazuje personalizam M. Schelera kao reakcija protiv Kantove etike. Iznosi se shvaćanje personalizma J. Lacroixa i E. Mouniera te njegova uloga u reviji Esprit. ${ }^{13}$

\subsection{Personalizam iz perspektive sovjetskih $i$ istočnoeuropskih rječnika}

Do 1963. u Sovjetskom Savezu ignorirani su moderni filozofski pravci na Zapadu. Tada se pojavljuje prvi filozofski rječnik u kojem se spominju nemarksistički mislioci. ${ }^{14}$ Naravno, u negativnom kontekstu, ali i to je bilo znatan pomak za ondašnje prilike. U Filozofskoj enciklopediji personalizam se određuje kao teistička, suvremena buržoaska filozofija koja daje primat osobi, a iznad nje je vrhovna osoba - Bog. Navode da se personalizam formirao krajem 19 st. u Rusiji i SAD-u, a potom 1930-ih godina u Francuskoj i drugdje. U Rusiji su personalizam razvijali N. Berdjajev, Lav Šestov (1886-1938), Nikolaj Onuferievič Losskij (1870-1965) i Sergej Bulgakov (1871-1944) te se prema tim misliocima, osobito Berdjajevu, izražava negativan stav. Zaključuju da je to iracionalna buržoaska filozofija kapitalizma. ${ }^{15}$

Manje je kritičan tekst u sovjetskom Filozofskom rječniku iz 1980-ih. Personalizam je označen kao idealističko učenje kojem je ključan pojam osoba, a rasprostranjen je u buržoaskim filozofijama od kraja 19. st. Kao osnivača navode B. P. Bownea, a uz njega vežu još Mary Whiton Calkins (1863-1930), Alberta Corneliusa Knudsona (1873-1953), Ralpha Tylera Flewellinga (1871-1960) i E. S. Brightmana. Kao engleskog predstavnika navode Herberta Wildona Carra (1857-1931), a njemačkog W. Sterna. Kao francuske personaliste prepoznaju E.

\footnotetext{
${ }^{11}$ André LALANDE, Vocabulaire technique et critique de la philosophie: revu par mm. les membres et correspondants de la societe francaise de philosophie et public, avec leurs corrections et observations, Paris, Presses Universitaires de France, 1960, 756-757.

${ }^{12}$ Paul FOULQUIÉ, Dictionnaire de la langue philosophique, Paris, Presses Universitaires de France, 1982, 532-533.

${ }^{13}$ Jean-Louis DUMAS, Personnalisme, u: Sylvain AUROUX (ur.), Les notions philosophiques. Dictionnaire, sv. 2, Paris, Presses Universitaires de France, 1990, 1911-1912.

${ }^{14}$ M. M., Znatan napredak. U povodu najnovijeg izdanja Filozofskog rječnika, Moskva, 1963, Naše teme, 8 (1964) 10, 1732-1735.

${ }^{15}$ I.BALAKINA,K.DOLZOV,Персоналйзм (personalism), u:Fodor VasilevičKONSTANTINOV (ur.), Филособская энциклопедия, 4, Moskva, Izdateljstvo Sovetska enciklopedia, 1967, 242244.
} 
Mouniera i J. Lacroixa. Kao jedan od ciljeva personalizma navode »zaštitu mira i buržoaske demokracije ${ }^{16}$

Sovjetska određenja slijede se i u istočnonjemačkom filozofskom rječniku. Pod pojmom personalizma navode se dva značenja. Prvo, kao Schleiermacherov pojam kojeg koriste Goethe i Feuerbach da bi izrazili vjerovanje u osobnog Boga. U drugom značenju to je naziv za subjektivno-idealistički, agnostički i religiozni oblik imperijalističke filozofije. Navode da je nastao u tri oblika: $u$ SAD-u kao struja pragmatizma; u Njemačkoj kao psihološko-pedagoško učenje te u Francuskoj kao sporedni tok kršćanskog egzistencijalizma. Objašnjavaju da je svima njima u središtu razmatranja »osoba« koja nije čovjek pojedinac ili društveno-povijesna veličina, već duhovna kategorija. ${ }^{17}$

Poljski publicist, australski sveučilišni profesor Jozef Wilczynski (1922-1984) objavio je niz djela tijekom hladnog rata u kojima upoznaje Zapad sa socijalističkim poimanjem svijeta. U opširnom Enciklopedijskom rječniku marksizma, socijalizma i komunizma obrađuje i personalizam te odnos marksizma prema tom pravcu. Navodi da je personalizam filozofski pokret koji se temelji na prihvaćanju osobe kao primarne stvarnosti i duhovne odrednice bića. Ukratko opisuje osnovne karakteristike personalizma, a kao glavne eksponente ističe B. P. Bownea, E. S. Brightmana, E. Mouniera i L. V. Sterna. Iznosi da se marksistička filozofija snažno protivi personalizmu smatrajući ga jednim od ekstremnih oblika idealizma s elementima religije, a što nije u skladu s materijalizmom i marksističkim stavom da društvo određuje osobu, a ne obrnuto. ${ }^{18}$

\subsection{Personalizam iz perspektive anglosaksonskih $i$ američkih rječnika $i$ enciklopedija}

Londonski profesor filozofije Stuart Brown navodi da pojam personalizam potječe od Schleiermachera te da su J. Maritain, E. Mounier i Luigi Stefanini (1891-1956) kao katolici zastupali personalizam protiv naturalističkih i materijalističkih filozofija. Iz sličnih razloga to su radili i neki apsolutni idealisti koje povezuje s personalizmom - Edward Caird (1835-1908), M. W. Calkins i Thomas Hill Green (1836-1882). Misli da su svi koji se nazivaju "personalistima« reakcija na tada prevladavajuću tradiciju apsolutnog idealizma. U tu skupinu svrstava E. S. Brightmana, H. W. Carra, Georgea Holmesa Howisona (18341916), Hastingsa Rashdalla (1858-1924) te Clementa Charlesa Juliana Webba

\footnotetext{
${ }^{16}$ Ivan Timofejevič FROLOV, Персоналйзм, u: Ivan Timofejevič FROLOV (ur.), Философский словарь, Moskva, Izdateljstvo političeskoi literaturi, 1980, 279-280.

${ }^{17}$ Manfred BUHR, Personalismus, u: Klaus GEORG, Manfred BUHR (ur.), Philosophisches Wörterbuch, Leipzig, VEB Bibliographisches Institut, 1976, 415.

${ }^{18}$ Jozef WILCZYNSKI, An Encycolopedic Dictionary of Marxism, Socialism And Communism: Econimc, Philosophical, Political and Sociological Theories, Concepts, Institutions and Practices. Classical and Modern, East-West Relations Included, Berlin - New York, De Gruyter, 1981, 430.
} 
(1865-1954). Po njemu, neki su personalisti bili i realisti, kao što su AndrewSeth Pringle-Pattison (1856-1931) i James Bissett Pratt (1875-1944). Ferdinanda Canninga Scotta Schillera (1864-1937) i njegovu kombinaciju pragmatizma i personalizma smatra svijetom za sebe. Personalizam Johna Macmurraya (18911976) shvaća kao reakciju na šire kulturne utjecaje koji depersonaliziraju ljude, osobito na mehanicistički i redukcionistički trend u filozofiji. Smatra da isto vrijedi i za Antonia Casoa (1883-1946). Spominje i da je personalizam utemeljio škole na sveučilištima u Bostonu i Južnoj Kaliforniji. Podsjeća i na personalistički američki časopis The Personalist osnovan 1919., a preimenovan u Pacific Philosophical Quarterly 1980. ${ }^{19}$

U Rječniku filozofije religije personalizam se određuje kao pokret koji daje središnju ulogu osobi u teodiceji, etici i teologiji. B. P. Bownea smatraju osnivačem, a kao istaknute personaliste navode E. S. Brightmana i Petera Anthonya Bertoccija (1910-1989). Završno napominju da je baptistički pastor i borac za ljudska prava Martin Luther King (1929-1968) bio pod utjecajem svojih bostonskih personalističkih profesora. ${ }^{20}$

Personalizam se određuje kao teorija, uglavnom američkog podrijetla iz 20. st. u Rječniku filozofije. Za personalizam je osoba ontološki temeljni pojam, a sva filozofska pitanja se razmatraju u odnosu na osobu. Po karakteru personalizam određuju kao idealistički smjer, a označavaju ga i teističkim jer uzima Boga kao primarnu manifestaciju osobnosti. ${ }^{21}$

Blackwellov rječnik zapadne filozofije personalizam definira kao filozofski pokret koji je procvjetao početkom 20. st. u SAD-u s G. H. Howisonom, B. P. Bowneom i E. S. Brightmanom. Prikazuje se njihova središnja doktrina prema kojoj je osoba ontološka krajnost i gdje osobnost ima najveću vrijednost. Kao europske personaliste određuju E. Mouniera, J. Maritaina i Étiennea Gilsona (1884-1978). U personalizam svrstavaju i filozofiju probabilizma Franka Plumptona Ramseya (1903-1930), Brune de Finettija (1906-1985) i Leonarda Jimmiea Savagea (1917-1971). ${ }^{22}$

U Cambridgeovom rječniku filozofije članak o personalizmu piše Cornelius F. Delaney (r. 1938) profesor filozofije Sveučilišta Notre Dame. Personalizam razumijeva kao verziju osobnog idealizma koji je cvjetao na Sveučilištu u Bostonu od kraja 19. do sredine 20. st. Glavni zagovornici su B. P. Bowne i tri njegova učenika: A. Knudson, R. T. Flewelling i E. S. Brightman. Korijene personalizma vide u učenju Georgea Berkeleya (1685-1753) i Gottfrieda Wilhelma Leibniza

\footnotetext{
${ }^{19}$ Stuart BROWN, Personalism, u: Stuart BROWN i dr. (ur.), Biographical Dictionary of Twentieth-century Philosophers, London - New York, Routledge, 2002, 889-890.

${ }^{20}$ Charles TALIAFERRO, Elsa J. MARTI, Personalism, u: Charles TALIAFERRO, Elsa J. MARTY (ur.), A Dictionary of Philosophy of Religion, London - New York, Continuum, 2010, 176.

${ }^{21}$ Antony FLEW, Personalism, u: Antony FLEW (ur.), A Dictionary of Philosophy, London, Macmillan Press, 1984, 265-266.

${ }^{22}$ Nicholas BUNNIN, Jiyuan YU, The Blackwell Dictionary of Western Philosophy, Oxford, Blackwell Publishing, 2004, 513.
} 
(1646-1716). Ukratko se prikazuju osnove Bowneove i Brightmanove filozofije te spominje francuska verzija personalizma na neoskolastičkoj tradiciji E. Mouniera, J. Maritaina i E. Gilsona. ${ }^{23}$

Članak o personalizmu u Routledgovoj filozofskoj enciklopediji potpisuje profesor filozofije na Sveučilištu Wisconsin, Keith E. Yandell (r. 1938). Navodi da je personalizam teza da samo osoba (samosvjesni djelatelj), njeno stanje i karakteristike postoje te da se stvarnost sastoji od društva interaktivnih osoba. Tipičnost personalista vidi u stavu o postojanju i kontinuitetu osobe s Bogom koji je Vrhovna osoba s inteligencijom i voljom. Personaliste određuju uglavnom kao idealiste u metafizici s tendencijom neutilitarnosti u etici. Razjašnjava da pojam "personalizam« ima mnogo oblika, pa i ateistički u koji svrstava Johna McTaggarta Elilisa McTaggarta (1866-1925). U apsolutni idealistički personalizam ubraja G. W. F. Hegela, J. Roycea i M. W. Calkins, a u teistički personalizam B. P. Bownea, E. S. Brightmana i P. Bertocija. G. W. Leibniza i G. Berkeleya vidi kao rane personaliste, a za I. Kanta smatra da nije strogo uzimajući personalist, ali da je imao velik utjecaj na personalizam. ${ }^{24}$

Najopširnije određenje personalizma postoji u Standfordskoj enciklopediji filozofije. ${ }^{25}$ Članak potpisuju teolog i profesor na više američkih sveučilišta Thomas D. Williams (r. 1962) i Jan Olof Bengtsson (r. 1960), profesor na Sveučilištu Lund i Oxford. Na početku navode poteškoće oko definiranja i postojanja više različitih oblika personalizma. Smatraju da mnoge filozofske škole imaju nekog filozofa kojeg se može svrstati u personalizam. Pozivaju se na izjavu J. Maritaina o postojanju desetak različitih personalističkih doktrina, a kojima je svima zajednički pojam »osoba«. Opširno pišu o povijesnim izvorima personalizma, da bi se u trećem djelu članka posvetili »europskom personalizmu« $u$ kojeg svrstavaju E. Mouniera, J. Maritaina, G. Marcela, Denisa de Rougemonta (1906-1985) i Paula Ricoeura (1913-2005). Opisuju i nastanak personalizma u Njemačkoj uz kojeg vežu Edmunda Husserla (1859-1938), M. Schelera, Dietricha von Hildebranda (1889-1977), Romana Ingardena (1893-1970) i Edith Stein (1891-1942). Spominju i lublinsku personalističku školu te nauk Karola Wojtyłe. U poglavlju o američkom personalizmu kao glavne autore spominju B. P. Bownea, G. H. Howisona i E. S. Brightmana, a navode još i A. C. Knudsona, Francisa Johna McConella (1871-1953), Georgea Alberta Coea (1861-1951), R. T. Flewellinga, Waltera Georgea Mueldera (1907-2004), P. Bertoccija, Gordona Villarda Allporta (1897-1967) i M. L. Kinga. Napominju da se američki personalizam ne može svesti samo na bostonsko sveučilište te da je cvjetao i na drugim sveučilištima. Posebno navode sveučilište Harvard, gdje snažne personalističke

\footnotetext{
${ }^{23}$ Cornelius F. DELANEY, Personalism, u: Robert AUDI (ur.), The Cambridge Distionary of Philosophy, Cambridge, Cambridge University Press, 1999, 661.

${ }^{24}$ Keith E. YANDELL, Personalism, u: Edward CRAIG (ur.), Routledge Encyclopedia of Philosophy, sv. 7, New York, Routledge, 2005, 315-318.

${ }^{25}$ Usp. Perosonalism, u: Stanford Encyclopedia of Philosophy, (12.11.2009; revidirano 11.05.2018) https://plato.stanford.edu/entries/personalism/ (25.01.2019).
} 
elemente nalaze kod Williama Jamesa (1842-1910), J. Roycea, Williama Ernesta Hockinga (1873-1966) i Charlesa Hartshornea (1897-2000). Ukratko prikazuju i ekvivalente personalizmu u drugim dijelovima svijeta.

\subsection{Personalizam iz perspektive kršćanskih/katoličkih rječnika}

U Westminsterskom rječniku kršćanske teologije za personalizam se navodi da je to filozofsko stajalište koje uzima kao polaznu točku ljudsku osobnost, a koja je glavni ključ prema središnjim metafizičkim problemima. Spominje da su mnogi personalisti postavili osobnog Boga kao ključ za razumijevanje konačne prirode svijeta. Navodi se da se mislioci poput M. Bubera i N. Berdjajeva određuju kao personalisti, ali da taj pojam najbolje opisuje bostonske filozofe B. P. Bownea i E. S. Brightmana. ${ }^{26}$

U Novoj katoličkoj enciklopediji personalizmom smatraju svaku filozofiju koja inzistira na realnosti osobe-čovjeka, anđeoske ili božanske te da se tim pojmom najčešće označava kretanje u filozofiji 19. st. koje je reakcija na materijalizam, evolucionizam i idealizam. Navodi se da se kod personalizma stavlja velik naglasak na osobu kao najvišu vrijednost i ključan pojam koji daje smisao sve stvarnosti. Personalizam shvaćaju kao reakciju na krajnji materijalizam 18. st., odnosno na mislioce kao što su Claude Adrien Helvetius (1715-1771), Paul Heinrich Dietrich von Holbach (1723-1789), Charles Darwin (1809-1882)., kao i na sljedbenike Isaca Newtona (1642-1717). Značajan formativni čimbenik razvoja personalizma vide i u protestu protiv apsolutizma Georga Wilhelma Friedricha Hegela (1770-1831). Kao prominentne europske personaliste određuju Ch. B. Renouviera, Maurice Blondela (1861-1949) i E. Mouniera. Drže da i egzistencijaliste, kao što su Gabriel Marcel (1889-1973), Jean Paul Sartre (19051980) i N. A. Berdjajev te istaknute tomiste, kao što su J. Maritain, Yves Simon (1903-1961) i E. Gilson, treba smatrati personalistima. ${ }^{27}$

Zanimljivu podjelu katoličke filozofije, u koju svrstava i personalizam, iznosi Alan Vincelette, profesor filozofije na više američkih sveučilišta. Bez obrazloženja kriterija za izbor, katoličke filozofe 20. stoljeća dijeli u sedam pokreta iznoseći po tri njihova reprezentativna predstavnika: 1. fenomenologija (E. Stein, D. von Hildebrand i Enrique Dussel); 2. neotomizam (É. Gilson, J. Maritain i K. Wojtyła); 3. transcendentalni tomizam (Pierre Rousselot, Karl Rahner i Bernard Lonergan); 4. personalizam (Ferdinand Ebner, E. Mounier i M. G. Nédoncelle); 5. egzistencijalizam (Louis Lavalle, G. Marcel i Xavier Zubiri y Apalátegui); 6. analitička filozofija (Elizabeth Anscombe, Charles Taylor

\footnotetext{
${ }^{26}$ Alan RICHARDSON, John BOWDEN, The Westminster Dictionary of Christian Theology, Philadelphia, Westminster Press, 1969, 443-444.

${ }^{27}$ J. A. MANN, Personalism, u: Thomas CARSON, Joann CERRITO (ur.), New Catholic Encyclopedia, sv. 11, Pau-Red, Detroit - Washington, Thompson Gale - The Catholic University of America, 2003, 152-153.
} 
i Francis Jacques) i 7. postmodernizam (Jean-Luc Marion, Jean-Yves Lacoste i William Desmond). ${ }^{28}$

\subsection{Personalizam iz perspektive hrvatskih rječnika}

U našoj enciklopedistici rijetko se spominje personalizam. U Hrvatskoj enciklopediji Leksikografskog zavoda Miroslav Krleža personalizam se određuje kao filozofski i teološki nauk po kojem je ljudska osoba najveća vrijednost, središte spoznaje i svrha etičkoga djelovanja. Kao početna točka u personalističkoj filozofiji naznačena je »osobnost koja je model sveukupne zbilje ${ }_{.}^{29}$ Ističe se da su se terminom prvi služili W. Whitman i A. B. Alcott, ali da se personalizam tek početkom 20. st. nastaje kao filozofski nazor u Ch. Renouviera i W. Sterna te posebice u M. Schelera, kao vrijednost ostvarena u čistom aktu (jer subjekt je taj po kojem postoje vrijednosti). Nadalje se navodi:

»U fenomenološkim etikama personalizam je intencionalni akt, tj. neposredno jedinstvo u sudoživljaju. Personalističke su pak nazore G. W. Leibniz i G. Berkeley baštinili iz Heraklitova i Sokratova filozofskog sustava (poslije i Borden Parker Bowne, George Holmes Howison, J. Royce i M. Buber). Kršćanski personalizam E. Mouniera u središte stavlja odnos osobe i ljudskoga društva. Osoba u Mouniera nije svediva ni na individuu ni na kolektiv, već je duhovna stvarnost koja teži vječnosti. Mounier naglašava međusobne odnose osoba, uz očuvanje osobne slobode, pronalazeći svojevrstan most između kršćanstva i egzistencijalizma. Srodna filozofska gledišta zastupali su i N. A. Berdjajev, G. Marcel i J. Maritain. $\ll^{30}$

Sveučilišni profesor filozofije Anto Mišić u Rječniku filozofskih pojmova za personalizam navodi:

»Filozofski nauk koji promatra osobu kao središnji, ontološki, gnoseološki, moralni i sociološki princip. Pojam je počeo koristiti Ch. Renouvier (Le personnalisme, 1903.) da bi označio vlastitu filozofiju u kojoj je nastojao braniti vrijednost ljudske osobe, a protiv apsolutnog panteizma njemačke filozofije ili naturalističkog pozitivizma francuske filozofije. Novi zamah personalizam dobiva kod E. Mouniera koji je osnovao časopis Esprit (1932.), oko kojeg je pokrenuto i društveno-političko zauzimanje. Protiv individualizma i kolektivizma naglašava vrijednost pojedinca (osobe) i zajedništva. «11

\footnotetext{
${ }^{28}$ Alan VINCELETTE, Recent Catholic Philosophy. The Twentieth Century, Milwaukee, Marquette University Press, 2011, 7.

${ }^{29}$ Personalizam, u: Hrvatska enciklopedija. Mrežno izdanje, (2018) http://www.enciklopedija.hr/ natuknica.aspx?id=47742 (25.01.2019).

${ }^{30}$ Isto.

${ }^{31}$ Anto MIŠIĆ, Rječnik filozofskih pojmova, Split, Verbum, 2000, 203.
} 


\section{Personalizam u Francuskoj (»francuski« personalizam)}

Na europskom kontinentu personalizam se obično veže uz tri škole: francusku u Parizu, njemačku u Göttingenu i Freiburgu te poljsku u Lublinu. Personalizam je imao odjek i u drugim europskim državama. U Francuskoj personalizam nije bio samo filozofski pravac, već je imao brojne sljedbenike $u$ različitim personalističkim pokretima. Nakon Drugoga svjetskog rata personalizam je postao i sastavni dio programa različitih političkih stranaka, a osobito demokršćanskih.

\subsection{Početak francuskog personalizma i opća određenja}

Početak francuskog personalizma 20. st. neki smještaju u 1903. godinu kada je Ch. Renouvier objavio djelo Le personnalisme u kojoj je prvi put predložen personalizam kao novi filozofski sustav koji brani vrijednost ljudske osobe protiveći se apsolutnom panteizmu njemačke i naturalističkom pozitivizmu francuske filozofije. Renouvier zastupa tzv. »relativistički personalizam« kojeg karakterizira empirizam, relativizam, finitizam i pluralizam naglašavajući osobno iskustvo, Božju moć, ljudsku slobodu i besmrtnost..$^{32}$ Renouvierov izvorni doprinos personalizmu jest ideja da se svaka vrsta zajednice mora graditi na prvenstvu pojedinca, izbjegavajući anarhističke i liberalne iluzije. Albert Bazala u Povijesti filozofije kao najvažnijeg predstavnika francuskog neokriticizma spominje Ch. Renouviera, ${ }^{33}$ ali ga ne veže uz personalizam. To pokazuje da do 1930-ih godina personalizam uglavnom nije prepoznat kao filozofski pravac ili neko zasebno filozofsko kretanje. Da personalizam Renouviera nije bio impuls za personalizam 1930-ih godina potvrđuje i Mounier priznajući da je u francuskim okvirima riječ personalizam prvi upotrijebio Renouvier, ali u zastarjelom obliku te da se ponovno pojavio početkom 1930-ih u posve drugom ozračju, osobito s obzirom na tadašnju političku i duhovnu krizu u Europi. ${ }^{34}$

Profesor političkih znanosti na Sveučilištu u Grenoblu Jean-Luc Chabot (r. 1944) u personalizam 20. stoljeća svrstava D. von Hildebranda, R. Guardinija, F. Ebnera, M. Bubera, L. Stefaninija, Luigija Pareysona (1918-1991), B. P. Bownea, G. H. Howisona, Cornelija Fabra (1911-1995) i Juliána Mariasa (1914-2005). Od Francuza navodi E. Mouniera, J. Maritaina, G. Marcela, Mauricea Nédoncellea (1905-1976), J. Lacroixa i Emmanuela Levinasa (1906-1995). Navodi i da su J. P.

\footnotetext{
${ }^{32}$ Rufus R. BURROWS, Personalism. A Critical Introduction, St. Louis, The Chalice Press, 1999, 48.

${ }^{33}$ Albert BAZALA, Povijest filozofije, sv. 3, Povijest filozofije najnovijega doba, Zagreb, Matica hrvatska, 1912, 289-292.

${ }^{34}$ Emmanuel MOUNIER, Le personnalisme, Paris, Presses universitaires de France, 1969, 5.
} 
Sartre, E. Husserl, M. Scheler, Aleksandar Koyré (1892-1964) i P. Ricoeur bliski personalizmu. ${ }^{35}$

Luk Bouckaert (r. 1941), profesor etike na sveučilištu u Luevenu opisuje tri glavne struje francuskog personalizma. Prva je mreža pisaca i umjetnika predvođena J. Maritainom. Druga skupina je nastala oko Alexandra Marca (Alexandr Markovitch Lipiansky, 1904-2000), koji je zajedno s Robertom Aronom (1898-1975), Arnaudom Dandieuom (1897-1933), Henri Daniel-Ropsom (1901-1965) i D. de Rougemontom utemeljio časopis Ordre Nouveau. Ta skupina razrađuje ideju federalizma kao način izlaza iz liberalizma i totalitarizma. Treća skupina, koju smatra »najizdržljivijom« je ona koja se 1932. formirala oko časopisa Esprit, okupljena oko E. Mouniera i Georgea Izarda (1903-1973). ${ }^{36}$ Smatra da sve te različite grane personalističkog stabla ujedinjuje isto stajalište prema ljudskoj osobi. Ističe da personalističkim misliocima nije bila primarna namjera iznaći novu akademsku teoriju o osobi, već pronaći praktičnu filozofiju angažmana. To potkrjepljuje i činjenicom da nekoliko personalista nije izabralo akademsku karijeru, već istraživanje različitih fenomena gospodarske, političke i kulturne krize kao simptoma globalne krize civilizacije. Smatra da su otuda crpili i retoriku »novog poretka«, »duhovne revolucije«, »radikalnih reformi« i »ponovnog rođenja« koju su podržavale inovativne ideje o političkom federalizmu, trećem putu gospodarstva i dokidanju ljudskog otuđenja.

Jean-Louis Loubet del Bayle (r. 1940), profesor na Institutu političkih znanosti u Toulouseu, razumijeva tzv. »ne-konformiste 30 -ih« kao grupe i pojedince u međuratnom razdoblju u Francuskoj koji su bili u potrazi za novim rješenjima političke, gospodarske i socijalne krize. U nekonformiste svrstava grupu oko E. Mouniera i revije Esprit, grupu Orde nouveau pokrenutu od strane A. Marca i skupinu Jeune Droite, koja je okupljala intelektualce koji su se nadahnjivali francuskim pokretom Action Française. ${ }^{37}$

Profesor filozofije na Sveučilištu Xavier u Cincinnatiju Bernard A. Gendreau navodi da se personalizam u Francuskoj u prvoj trećini 20. st. ogleda u spisima Ch. Renouviera, M. Blondela, H. Bergsona, Ch. Peguya, Luciena Laberthonnièrea (1860-1932), Paula Archambaulta (1883-1950), D. de Rougemonta, Pierrea Teilharda de Chardina (1881-1955), N. Berdjajeva, G. Marcela te J. Maritaina i E. Mouniera. ${ }^{38}$

\footnotetext{
${ }^{35}$ Jean-Luc CHABOT, Le courant personnaliste et la Déclaration Universelle des Droits de l'Homme, Persona y Derecho, 46 (2002) 73-95.

${ }^{36}$ Luk BOUCKAERT, Introduction: personalism, Ethical Perspectives, 6 (1999) 1, 1-3.

${ }^{37}$ Jean-Louis Loubet DEL BAYLE, Les non-conformistes des annees 30. Une tentative de renouvellement de la pensée politique française, Paris, Edition du Seuil, 1969.

${ }^{38}$ Bernard A. GENDREAU, The Role of Jacques Maritain and Emmanuel Mounier in the Creation of French Personalism, The Personalist Forum, 8 (1992) 1, 97-108.
} 


\subsection{Personalizam kao pokret}

Kod francuskog personalizma bitno je razlikovati personalizam kao filozofski pravac i personalistički pokret. N. Berdjajev, J. Maritain, G. Marcel, É. Gilson i drugi mislioci rođeni 1870-ih i 1880-ih godina u filozofskom smislu su do 1930-ih godina iznijeli već prepoznatljivu personalističku filozofiju. Početkom 1930-ih mlađi, često njihovi studenti i slušači oduševljeni pretvaraju taj nauk u pokrete. U tim pokretima, pored filozofa, sudjeluju književnici, novinari, glazbeni i likovni umjetnici te druga mlada inteligencija. Otuda ne začuđuje da katolički intelektualac Pascal Balmand opisuje personaliste tridesetih godina kao »aristokraciju intelektualnih proroka ${ }^{39}{ }^{39}$

Profesor političkih znanosti Ferdinand Kinsky navodi tri personalističke grupe. Prvo ističe Ordre nouveau koju je utemeljio A. Marc. Smatra da su oni imali za cilj pripremiti uvjete za »duhovni preporod« europske kulture. Svoje izvore su crpili iz kršćanskog egzistencijalizma Kierkegaarda, historicizma Péguyja, federalizma Proudhona i velike kritike modernosti Nietzschea. Kao istaknutije mislioce te skupine ističe R. Arona, A. Dandieua, Daniel-Ropsa, J. Jardina i D. de Rougemonta. Druga skupina je okupljena oko revije Esprit i E. Mouniera, koja u početku tijesno surađuje s Ordre nouveau. Napominje da se Esprit grupa kao reakcija na događaje Drugog svjetskog rata radikalno prebacila na lijevu političku stranu, a potom opet vratila na umjereniji položaj »nove ljevice«. Kao treću skupinu ističe mlade mislioce skupine Jeune Droite, disidente iz francuskog reakcionarnog i monarhističkog pokreta Açtion française. Kao njihove predstavnike navodi Jeana de Fabrèguesa (1906-1983), Jean-Pierrea Maxencea (1906-1956) i Thierrya Maulniera (1909-1988). U personaliste uključuje i one mislioce koji su članovima personalistčkih pokreta bili nadahnuće: W. Stern, M. Blondel, M. Buber, M. Nédoncelle, Karl Barth, G. Marcel, J. Maritain i N. Berdjajev. ${ }^{40}$

\subsection{Osobno poznavanje i personalistički »kružoci«}

Značajna karakteristika francuskog personalizma je i međusobno osobno poznavanje tih mislilaca, ne samo u okviru akademskih i kulturnih institucija, već i putem prijateljskih susreta i druženja. Godine 1928. A. Marc počinje organizirati susrete u klubu $d u$ Moulin Vert, gdje se susreću pariški intelektualci i razgovaraju o problemima svog vremena, osobito s pozicija triju kršćanskih tradicija - protestantizma, katolicizma i pravoslavlja. Skupina je uključivala vo-

\footnotetext{
${ }^{39}$ Pascal BALMAND, Intellectuel(s) dans l'ordre nouveau (1933-1938): une aristocratie de prophètes, u: Danielle BONNAUD-LAMOTTE i dr. (ur.), Intellectuel(s) des années trente, entre le rêve et l'action, Paris, Éditions du CNRS, 1989, 171-184.

${ }^{40}$ Ferdinand KINSKY, Personalism and Federalism, Publius - the Journal of Federalism, 9 (1979) $4,131-156$.
} 
deće protestantske pastore, katoličke intelektualce te ruske emigrantske mislioce. Krajem 1920-ih i početkom 1930-ih godina u Ruskom domu na pariškom Boulevard Montparnasse, zahvaljujući inicijativi N. Berdjajeva, održavali su se susreti pravoslavaca s francuskim katolicima i protestantima na kojima je osobito bio aktivan Maritain. Sudjelovali su Charles Du Bos (1882-1939), G. Marcel, Louis Massignon (1883-1962), E. Mounier i mnogi drugi. ${ }^{41}$ Manja grupa iz Ruskog doma sastajala se potom u domu N. Berdjajeva, a nakon toga i u domu J. Maritaina. Susreti u Maritainovom domu u Meudonu formalizirani su kao Cercle d'Etudes Thomistes. U njemu su sudjelovali filozofi N. Berdjajev, Oliver Lacombe (1904-2001), É. Gilson, E. Mounier i Peter Wust (1884-1940), teolozi Charels Journet (1891-1975) i Réginald Marie Garrigou-Lagrangre (1887-1964), književnici i publicisti Jean Cocteau (1889-1963), François Mauriac (1885-1970), Julien Green (1900-1998), Max Jacob (1876-1944) i François Fejtő (1909-2008), umjetnici Georges Rouault (1871-1958), Marc Chagall (1887-1985), Igor Fjodorovič Stravinski (1882-1971) i mnogi drugi. ${ }^{42} \mathrm{Na}$ tim kružocima sudjelovali su i oni koji nisu prihvaćali Tominu misao. Održavali su i godišnje duhovne vježbe za sudionike kružoka, a takav su pristup Jacques i njegova supruga Raïssa nagovijestili u zajedničkoj knjizi De la vie d'oraison (Molitveni život, 1922) u kojoj se zalažu za komplementarnost duhovnog i intelektualnog života.

Okupljali su se i u dekadama u Pontignyu koje je vodio C. Du Bos, a njima su pored navedenih, prisustvovali i André Gide (1869-1951), Roger Martin du Gard (1881-1958), André Maurois (1885-1967), M. Buber i mnogi drugi. Mjesto okupljanja bilo im je i krug Union pour la vérité, kojeg je osnovao Paul Desjardins (1859-1940). Berdjajev spominje i skupove Esprit, kao i one u domu G. Marcela. ${ }^{43}$ Iako su neki od navedenih u to vrijeme već bili poznati i priznati intelektualci, tek iz današnje perspektive možemo uvidjeti kakva je to bila koncentracija umova na jednom mjestu. Mnogi od njih su kasnije postali nobelovci, francuski akademici i dobitnici vrhunskih svjetskih priznanja.

O francuskom personalizmu tridesetih možda se najbolje izrazio sudionik personalističkog pokreta J. Lacroix. On navodi da je personalizam za njegove protivnike ideologija, a za njegove sljedbenike filozofija. Lacroix smatra da nije ni jedno ni drugo te da ta rasprava počiva na radikalnom nesporazumu. On tvrdi da je personalizam zapravo duboka i temeljna istina koja je došla na površinu u ljudskim umovima te da se stoga ne može opisati ni kao ideologija ni filozofija. ${ }^{44}$

\footnotetext{
${ }^{41}$ Nikolaj A. BERDJAJEV, Samospoznaja, Zagreb, Demetra, 2005, 252-260.

${ }^{42}$ François FEJTÖ, Od Budimpešte do Pariza preko Zagreba. Memoari, Zagreb, Nakladni zavod Matice hrvatske, 1989, 102; Marko KOVAĆEVIĆ, Pogovor, u: Jacques MARITAIN, Cjeloviti humanizam, Zagreb, Kršćanska sadašnjost, 1989, 365-375; Tomo VEREŠ, Sudbina Maritainove misli u Hrvatskoj, Marulić, 14 (1981) 2, 124-136.

${ }^{43}$ Berdjajev, Samospoznaja..., 252-260.

${ }^{44}$ Lacroix, Le personnalisme comme une anti-idéalogie..., 8.
} 


\section{Zaključak}

Vidljivo je da se personalizam određuje kao filozofija, filozofski pravac, disciplina, škola, nauk, pokret, teorija, učenje i slično. Pri tome, govor o personalizmu ima različite konotacije, prizvuke, naglaske i obojanost, ovisno i o povijesnom, geografskom, ili ideološkom kontekstu. Tako npr. možemo uočiti da se na germanskom području uz personalizam često veže misao F. Schleiermachera ili W. Sterna, na anglo-saksonskom području različiti američki protestantski mislioci (Bowne, Britghman i dr.), da se na »sovjetskom « području personalizam shvaćao više kao buržoaska ideologija, a ne sustavna filozofija i sl.

Iako se u različitim pokušajima određenja navodi da se kroz povijest filozofije mogu pratiti korijeni personalizma do antičkog doba, ipak se pojam personalizam u svim određenjima vremenski uobičajeno vežu uz 20. st. U svim određenjima se ukazuje i važnost pojma osobe i njezine uloge u zajednici, pa se otuda, načelno, personalizam može odrediti kao onaj smjer filozofije dvadesetog stoljeća koji u središte zanimanja stavlja osobu ${ }^{45}$ i namjenjuje joj dvostruku ulogu: a) osoba je apsolutno središte i norma za društvo i sve njegove institucije; b) osoba je osnova za naviještanje apsolutne univerzalnosti i solidarnosti među svim ljudima. ${ }^{46} \mathrm{U}$ većini tekstova ukazuje se i da je personalizam suprotan individualizmu te da je blizak kršćanskom poimanju svijetu i čovjeka.

U povijesnoj i zemljopisnoj difuziji ideja u modernoj misli postoji više oblika personalizma. Spominju se američki idealistički personalizam, ruski personalizam, različiti europski personalizmi, komunitarni kršćanski personalizmi i sl. Svaki od tih oblika ima svoje razumijevanje o osobi i stavlja je u središte filozofskog razmatranja. S obzirom na širinu onoga što se može razumijevati pod pojmom personalizma neki su zaključili da je »malo zajedničkog među različitim personalizmima, osim njihova protivljenja različitim oblicima materijalizma« te da »puna povijest personalizma tek treba biti napisana ${ }^{47} .7$

Iz različitih pokušaja određenja i navođenja predstavnika personalizma, možemo zaključiti da se u njihovom presjeku nalaze N. Berdjajev, J. Maritain i E. Mounier, kao tri najizrazitija predstavnika tog pravca, kao i da se personalizam uglavnom veže uz Francusku.

Korijeni francuskog personalizma obično se uočavaju u francuskom neokritizmu i tomizmu te njemačkom egzistencijalizmu, a vidljiv je i doprinos ruske religiozne filozofije koji nije dosada značajnije istražen. I površnim uvidom u personalizam i njegove pokrete moguće je uvidjeti aktivnost značajnog broja

\footnotetext{
${ }^{45}$ Ivan ŠESTAK, Stjepan Tomislav Poglajen - Kršćanski personalist, u: Stjepan Tomislav POGLAJEN, Kršćanski personalizam. Govori, članci, studije, Zagreb, Glas koncila, 2010, 7-48, 15.

${ }^{46}$ Thomas R. ROURKE, Rosita A. CHAZARRETA ROURKE, A Theory of Personalism, Oxford, Lexington Books, 2005, 10.

${ }^{47}$ Stanley RUDMAN, Concepts of Personhood and Christian Ethics, Cambridge, Cambridge University Press, 1997, 109.
} 
ruskih emigrantskih mislilaca. S obzirom na to da su u okviru personalističkih pokreta djelovali pravoslavci i katolici zajedno te da su im se pridružili i protestanti, možemo govoriti i o svojevrsnom »ekumenizmu prije ekumenizma«, odnosno o personalizmu kao istinskoj i cjelovitoj »kršćanskoj filozofiji«. Značajna karakteristika francuskog personalizma je i osobno poznavanje i druženje mislilaca i umjetnika koji su djelovali u personalističkim pokretima.

\section{Ivan Čulo* - Ivan Šestak**}

Comparative Approach to the Term, Concept and Phenomenon of Personalism

\section{Summary}

As mentioned before, personalism is being determined as a philosophy, philosophical direction, discipline, school, science, movement, theory, learning and the like. In this regard, descriptions of personalism have different connotations and accents depending on the historical, geographical or ideological context. Thus, for example in Germany personalism was associated with the the thought of F. Schleiermacher or W. Sterna, in the Anglo-Saxon world with various American protestant thinkers (Bowne, Britghman and others) and in the ex - Soviet area personalism was considered to be more of a bourgeois ideology than a systematic philosophy.

Although, throughout various attempts of determination of personalism in the history of philosophy one can follow the roots of personalism back to the antiquity, yet the term 'personalism' is dominantly determined by the $20^{\text {th }}$ century. All the determinations point out to the importance of the term 'person' and her/his role in the community, hence, in principle, personalism can be defined as the direction within the philosophy of the twentieth century which places the person in the center of interest and designates it a double function: a) the person is the absolute center and standard for society and all $i$ institutions; $b$ ) a person is the basis for proclaiming absolute universality and solidarity among all people. In most determinations, it is pointed out that personalism is opposed to individualism and is close to the Christian understanding of the world and man.

In the historical and geographical diffusion of ideas in modern thought there are many types of personalism. American idealistic personalism, Russian personalism, various European personalisms, communitarian Christian personalism etc. Each of these forms has its own understanding of the person and places

\footnotetext{
* Ivan Čulo, PhD, Institut Fontes Sapientiae; Address: Kušlanova 59, HR-10000 Zagreb, Croatia; E-mail: institutfs@gmail.com.

*** Ivan Šestak, PhD, Assoc. Prof., University of Zagreb, Faculty of philosophy and religious studies; Address: Jordanovac 110, HR-10000 Zagreb, Croatia; E-mail: isestaksj@gmail.com.
} 
it at the center of philosophical consideration. Given the breadth of what can be understood under the concept of personalism, some have concluded that „there is little in common among different personalisms apart from their opposition to the various forms of materialism" and that "full history of personalism stll has to be written".

From different personalistic determinations, as a cross section, one can conclude that Nikolai Berdyaev, Jacques Maritain and Emmanuel Mounier are its three most prominent representatives and that personalism is most often associated with France.

The roots of French personalism are commonly found in French neocritism and tomism, and German existentialism, and the contribution of Russian religious philosophy to French personalism has not been sufficiently explored yet. However, even a superficial glimps into the personalism and its movements provides the insight on the activities of a number of Russian emigrant thinkers. Since Orthodox and Roman Catholics acted together in the personalistic movements and that Protestants joined them, we can talk about a kind of 'ecumenism before ecumenism' or that personalism is a true and complete Christian philosophy.

Key words: personalism, european personalism, french personalism, Jacques Maritain, Nicolai Berdyaev. 